\title{
INNOVATIVE COMPONENT OF ECONOMIC SECURITY OF ENTERPRISES: A CASE OF THE REPUBLIC OF MOLDOVA
}

\author{
Alina IANIOGLO ${ }^{1}$, Tatjana POLAJEVA ${ }^{2}$ \\ ${ }^{1}$ Faculty of Economics, Comrat State University, Galatsan 17, MD-3805, \\ Comrat, Republic of Moldova \\ ${ }^{2}$ Faculty of Business Management, EuroAcademy, Tondi 55, 11316 Tallinn, Estonia \\ E-mails: 1'alina.ianioglo@gmail.com (corresponding author); ${ }^{2}$ tatjana.polajeva@gmail.com
}

Received 20 September 2017; accepted 12 November 2017

\begin{abstract}
In modern conditions of unpredictability, issues of ensuring the economic security of enterprise become particularly important and innovations are a significant component. The article aims to advance the knowledge of economic security and to develop the methodology of ensuring the economic security of enterprise and its innovative component. To achieve this goal, the following methods were used: systematization, data collection, analysis, comparison and the inductive method. The system of ensuring economic security was developed and the mechanism of increasing the innovative activity of enterprises in developing countries was determined, on example of the Republic of Moldova. The presented research results are important for the development of economic science as they represent a systematization of different approaches to economic security with the focus on its innovative component. The developed system, with its main phases and proposed measures, may be implemented by the management in order to strengthen the innovative activity and the economic security of enterprises, taking into account the features of a specific industry and the environment of a specific country.
\end{abstract}

Keywords: competitiveness, development, economic security, functional components, innovations, state support, threats.

JEL Classification: M21, O12, O31.

\section{Introduction}

In the modern open competitive environment, entrepreneurs assume most of the business risks. As it was noted by Hindle and Klyver (2011), in advanced economies, during the first five years, the attrition rate of new businesses varies "from around 80 per cent to around 50 per cent of the original cohort". Multiple threats may lead to negative consequences in the form of solvency and financial stability violations, profitability reduction and other deterioration in the enterprises' activity and in the whole economy. In this regard, the issues of ensuring economic security become particularly important.

Ensuring economic security is the basis of sustainable operation and development of the economic entity. Nowadays, the ensuring of economic security of enterprise is directly determined by the development and introduction of innovations in its activity. It 
is especially important for developing countries, where technological advances are the key to improving life. Innovation through the activities of research and development is deemed as a crucial driver of economic growth. Innovations represent an effective means of competition, since they lead to the creation of new needs, reduce production costs, inflow of investments, improve the image of new products manufacturer. But what methodology should entrepreneurs implement to ensure the innovative component of economic security? The article aims to advance knowledge in economic security and to develop the methodology of ensuring its innovative component.

Innovations are primarily meant to enhance the competitiveness of enterprises in the real sector of the economy, as well as the entire national economy, and secondly to increase the success of the companies in the business. Success in business can be achieved in several ways: the first way involves the use of cheap raw materials, and the second way involves the use of cheap labor. The third way involves the use of innovative technologies that improve productivity, product quality and its competitiveness. For a developing country like Moldova, one of the poorest countries in Europe, the first two options are not acceptable, because it practically does not have cheap raw material and the labor force decreases every year due to increased migration. Objectively, there is only the third way - the way of innovative development. However, appropriate conditions must exist.

The study is designed to fill the following 2 gaps in the economic science: to study deeply the concept of economic security by combining Western and Eastern studies in the field of economic security and determining the main approaches of its definition; and to develop the methodology of ensuring economic security of enterprise in a developing country on example of the Republic of Moldova by reviewing its innovation system and presenting measures of increasing the innovative component.

The article presents the meaning of economic security of enterprise and its innovative component; an overview of the innovation system in the developing country on the example of the Republic of Moldova; the system of ensuring economic security of enterprise and the mechanism of improving the innovative activity of enterprises.

The purpose of the article is to present the economic mechanism of improving the innovative activity of enterprises.

Research methodology. The article is a conceptual one and it is based on:

- the analysis and systematization of scientific literature;

- the collection and analysis of international data;

- a comparison of indicators from different countries;

- an inductive method that involves synthesis of empirically obtained data.

\section{Economic security of enterprise and its innovative component}

Sustainability and economic security are the main sources of the company's development opportunities (Raudeliūnienè et al. 2014).

The concept of security according to the etymology of this word means a lack of danger. The security involves the protection of basic necessities, physiological, socio-economic, 
spiritual and situational resources, technologies, information and moral ideals, required for the vital activity and prosperity of society (Tamošiūnienè, Munteanu 2015).

There are several types of security by content, depending on the areas of public life and the direction of human activities: political, economic, information, ecological, military and others. Economic security holds a special place among the various types of security, because not all of them can be sufficiently realized without the economic aspect. It is clear that with economic security other levels of security become easier to establish (Stone 2009).

The economic security is a complex idea that could be analyzed on three main levels: micro - individual persons, families; meso - enterprises, firms, business associations and macro - state, interstate relations, the world. The authors agree that although the macro - national level seems to be very important, it is the enterprises that are, in fact, generating "tax money" and jobs that decide on the appropriate level of economic security and the adoption of sustainability. That is why the meso level should be carefully monitored by the government (Wysokińska-Senkus, Raczkowski 2013).

The need for security is basic for the individual, enterprises, society and the state as a whole. Western scientists have focused on national economic security (Buzan, Hansen 2009), household economic security (Dynan 2016) and the economic security of the individual (Hacker et al. 2014). The economic school from Eastern countries has paid attention, in addition to the above "to economic security of the region and economic security of the enterprise" (Shutyak et al. 2014). At all stages of economic development, the enterprises are the main element of the economy and need to be secured from internal and external threats. In the economic literature there are various interpretations of the economic security of enterprise. Some definitions of economic security are presented in Table 1.

Analysis of the conceptual apparatus of economic security showed that this concept is considered from several points of view (Ianioglo, Polajeva 2016):

1. The first approach to the definition of the economic security of enterprise is based on the use of concept of protection from threats (D. Baldwin; N. Freeman; A. Suglobov; G. Vechkanov; L. Artemenko; K. Raczkowski).

2. The second approach, which consists in the fact that the economic security of enterprise is seen as a state of efficient use of resources, is closely related to the first approach (I. Stratan; S. Strelcova).

3. According to the third approach, economic security of enterprise is determined by the position of the ability for a stable functioning and development (V. Ioan-Franc; M. Diamescu).

4. According to another approach, the economic security of enterprise is defined as having a competitive advantage (A. Suglobov; M. Tsereteli).

5. V. Gaponenko and V. Tambovctsev examined economic security from the fifth position, achieving the goals.

It can be noted that many authors (I. Stratan; O. Vivchar, etc.) in their definitions of enterprise economic security adhere to a mixed approach. 
Table 1. Definitions of economic security

\begin{tabular}{ll}
\hline \multicolumn{1}{c}{ Author } & \multicolumn{1}{c}{ Definition } \\
\hline $\begin{array}{l}\text { D. Baldwin } \\
\text { (1997) }\end{array}$ & $\begin{array}{l}\text { Economic security is seen as a different form of security aimed at ensuring } \\
\text { minimal damage to a set of economic values. }\end{array}$ \\
\hline $\begin{array}{l}\text { N. J. Freeman, } \\
\text { F. L. Bartels } \\
\text { (2004) }\end{array}$ & $\begin{array}{l}\text { Economic security represents the safeguarding the structural integrityand } \\
\text { prosperity- generating capabilities and interests of politico-economic entity in } \\
\text { the context of various externalised risks and threats that confront it. }\end{array}$ \\
\hline $\begin{array}{l}\text { V. Gaponenko } \\
\text { et al. (2007) }\end{array}$ & $\begin{array}{l}\text { Economic security is a state of enterprise, which is characterized by its ability } \\
\text { to function properly in order to achieve its goals under the existing external } \\
\text { conditions and their change within certain limits. }\end{array}$ \\
\hline $\begin{array}{l}\text { V. Ioan-Franc, } \\
\text { M. Diamescu }\end{array}$ & $\begin{array}{l}\text { Economic security of economic agents provides appropriate conditions for } \\
\text { the stability of economic activity during each cycle of production, exchange, } \\
\text { distribution and consumption. }\end{array}$ \\
\hline $\begin{array}{l}\text { L. Artemenko } \\
\text { (2016) }\end{array}$ & $\begin{array}{l}\text { The security in the context of business management is the ability of } \\
\text { management to respond adequately to the threat of risk factors, including } \\
\text { internal weaknesses, using unused resources to function effectively. }\end{array}$ \\
\hline K. Raczkowski & $\begin{array}{l}\text { Economic security is defined as functioning of the state economy, relatively } \\
\text { balanced in endogenic and exogenic terms, where occurring risks of disturbed } \\
\text { balance are maintained within specified and approved organizational and legal } \\
\text { standards and principles of community life. }\end{array}$ \\
\hline
\end{tabular}

I. Stratan (2007) Economic security of enterprise is a state of the most efficient use of all resources in order to prevent (neutralize, eliminate) threats and ensure stable functioning of enterprise in a market economy.

S. Strelcova et al. Acording to the authors, enterprise perceives economic security, on the one (2015) hand, from the point of view of ensuring sufficient resources for realising activities in routine as well as emergency conditions and, on the other hand, from the point of view of return of the means invested.
A. Suglobov et al. (2013)
Economic security is a system that provides competitive advantages of enterprise through the effective use of resources based on the study of comprehensive information formed in the integrated accounting and information system.
V. Tambovctsev By him, under the economic security of a system is necessary to understand the (1995) totality of the properties of the state of its production subsystem that provides the ability to achieve the purpose of the whole system.

M. Tsereteli (2008)

The concept of economic security refers to the long-term security of access to economic opportunities, to markets, and to resources such as people (human capital), capital, energy, water, technology, and education.

\begin{tabular}{ll}
\hline $\begin{array}{l}\text { G. Vechkanov } \\
\text { (2007) }\end{array}$ & $\begin{array}{l}\text { The economic security of the enterprise is understood as the protection of its } \\
\text { scientific, technological, production and personnel potential from active or } \\
\text { passive economic threats. }\end{array}$ \\
\hline $\begin{array}{l}\text { O. Vivchar } \\
(2016)\end{array}$ & $\begin{array}{l}\text { Security business is a state corporate resources and business opportunities in } \\
\text { which guaranteed most effectively use them for stable operation and dynamic } \\
\text { scientific and technological and social development, prevention of domestic } \\
\text { and external negative influences. }\end{array}$ \\
\hline
\end{tabular}

Source: systematised by the authors. 
In our opinion, the economic security of enterprise is a state that characterizes the ability of an economic entity to ensure efficient use of resources and entrepreneurial opportunities to prevent possible threats and achieve stable functioning and business objectives. Ensuring the economic security of the enterprise is important for the implementation of the continuous process of reproduction.

The main areas of economic security of the enterprise: financial, personnel (human resources), production, technological and innovative components are four distinguished functional components. This structure is offered for an effective analysis of economic security.

1. The financial component of economic security of enterprise implies the condition of the most efficient use of corporate resources, which reflects in the best values of business profitability, its capital structure, financial stability, solvency and liquidity of its working capital, in quality management, etc.

2. The production component involves the efficient management of the production process. The sales volume, profitability indicators and others determine this component.

3. The personnel component. An employee can destroy the native organization or vice versa to achieve its prosperity. Even at the beginning of the 20th century, Ford (2003) said that if he had taken away all his automobile factories, but leave the people he would be able to restore his car empire. However, if, on the contrary, he will have only factories without people, he cannot do anything. Consequently, the personnel of the company is its most important resource, and at the same time is a potential source of major losses and even bankruptcy for the economic entity.

4. The essence of the technological component consists in how the level of technology used in the company meets the requirements of the present, the level of their competitiveness. The object of the technological component can be equipment, expertise, as well as the knowledge, skills and experience of the staff. The innovative component is closely connected with technological progress, and technological progress is "the result of the innovation process" (Rosca 2004).

In the current economic conditions innovations represent the main tool in improving production efficiency and product quality, reducing costs, increasing competitiveness and thereby ensuring the economic security of the enterprise. Innovations are an important component of the enterprise's economic security. Innovations are usually considered a potential transformation of scientific and technological progress into a real product or technology.

According to Trott (2008), innovation is the management of all activities involved in the process of idea generation, technology development, manufacturing and marketing of a new (or improved) product or manufacturing process or equipment.

There are several ways to achieve success in business: the use of cheap raw materials, cheap labor and the use of innovative technologies. For Moldova, the first two options are not acceptable, because it practically does not have cheap raw materials and the labor force decreases every year due to increased migration. Objectively, there is only 
the third way - the way of innovative development, which involves the use of innovative technologies that improve productivity, product quality and its competitiveness.

We can define the innovation process as a totality of consecutive actions for setting and implementing new technologies or the improvement of already existing ones. The performance of innovation in enterprise depends on the efficiency level of the main departments, including research and development department, marketing, finance and human resources department.

The management must ensure the innovative component of economic security of enterprises. In addition, the conditions for innovative development at the state level should be created. In this context, first we will first review the innovation system in the Republic of Moldova.

\section{Overview of the innovation system in the Republic of Moldova}

In the modern era characterized by constant crises, it became apparent that the crisis plays a dual role in the economic development and in the process of innovation. Pessimists see the crisis as a real threat to the development of innovative processes: the crisis undermines the financial basis for innovative growth, reduces the innovative capacity of national economies slows down the introduction of new products and business processes, as companies are afraid to invest in them because of the risk to growth and the decline in demand for such products (Blinder 2012). Moreover, many experts believe that if the economy can recover quickly after the crisis, the innovation market turns into depression for a long time, because scientists lose the qualification, students choose more profitable industries and other reasons. Optimists, including Peter Lindholm, innovation advisor at the World Bank, believe that the crisis is also, a good time for innovation, because when everyone is fighting for survival, those who invest in innovation can "shoot" as soon as the crisis is over. If you have money, it is a good time to invest in innovation, including for psychological reasons.

To understand how these relate to the Republic of Moldova, it is necessary to analyze the situation that prevailed in the country. Nowadays, in Moldova innovation has become trendy word. It is widely used in scientific and economic circles and in the mass media. Over the past ten years, Moldova's economy has gone through significant structural changes. The service sector has been the largest contributor to the economic growth, and tradable sectors, namely agriculture and manufacturing, have stagnated.

Usually, the more developed is the country is, the more money is spent on research and development by enterprises. According to IDIS "Viitorul" (2014) enterprises in the Republic of Moldova spend, on average, $2.3 \%$ of their total expenditures for R\&D activities.

For the analysis of the innovative activity of SMEs, we turn to the Global Innovation Index (GII 2017). This evaluates the effectiveness of innovation activities of 127 countries and economies around the world. According to the GII, the Republic of Moldova ranked 54 (out of 127 countries included in the analysis), is behind the following for- 
mer socialist countries: Czech Republic (24), Estonia (25), Slovenia (31), Latvia (33), Slovakia (34), Hungary (39), Lithuania (40) and Croatia (41).

For the last three years, the Republic of Moldova is ahead of its neighbors because of the use of indirect indicators, such as data on education, research and development; data on the creative patents, from which the Republic of Moldova has tangible results (Maier 2014).

An analysis of business innovativeness reveals that among the EU Member States, the highest R\&D intensities in 2015 were recorded in Sweden (3.28 per cent), Austria (3.12 per cent) and Denmark (2.96 per cent). According to Organization for Economic Cooperation and Development, gross domestic spending on R\&D as a percentage of GDP in the European Union was 1.96 per cent, and in the Republic of Moldova it was only 0.37 per cent (Fig. 1), that shows insufficient state support.

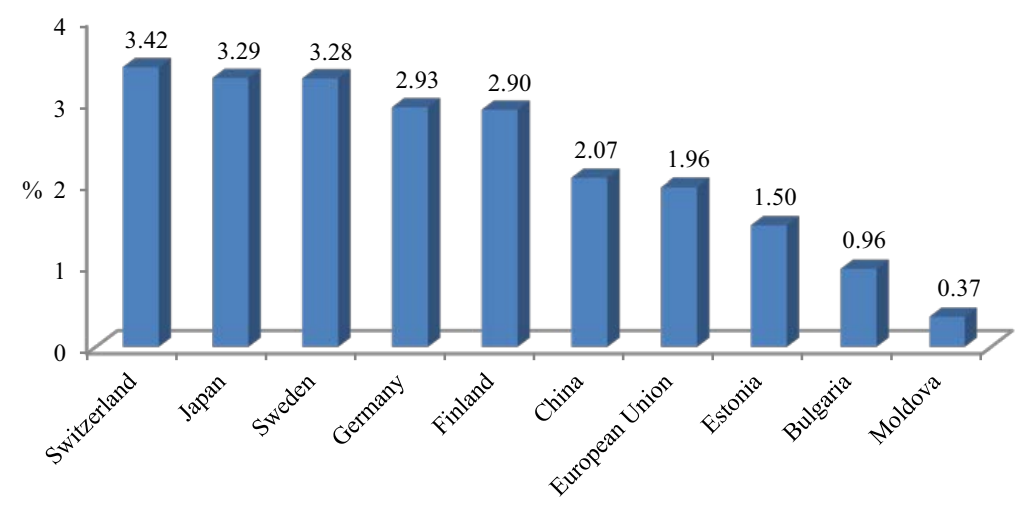

Fig. 1. Gross domestic spending on R\&D, percentage of GDP, 2015 Source: OECD (2017).

Therefore, the major factors, which are still constraining the innovative activity of the Republic of Moldova, are the shortage of financial resources and an insufficient level of state support. The economy cannot grow if there will not be changes in the economic structure, which is currently based on products that do not require more technology and on a structure of foreign direct investments, focused on monopoly investing in certain areas (for example, electricity, gas) and getting immediate profits.

At the national level, research along with education and innovation is recognized as one of the pillars of the country's development. The real situation, reflected by indicators, does not confirm the placing of research as a priority. The financial resources for science and innovation serve as an example, which are allocated from the budget, in absolute and relative terms (Fig. 2).

In the Code on science and innovation, the financial objective for R\&D\&I continues to reach ambiguous - up to 1 per cent of GDP, which could mean 0.2 per cent and 0.8 per cent. With such a weak funding of science and innovation, which tends to zero, 


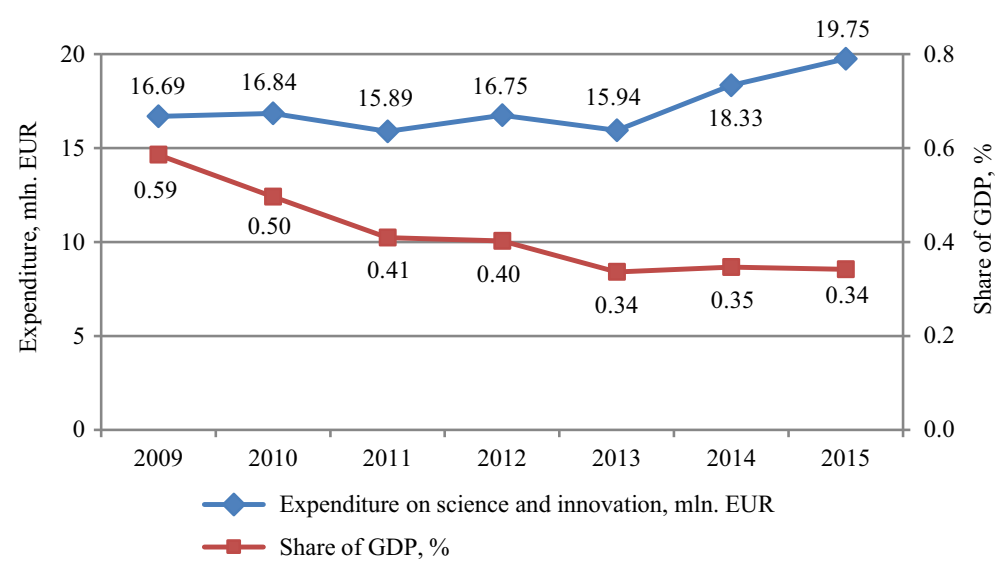

Fig. 2. Evolution of state budget financing of science and innovation in the Republic of Moldova, 2009-2015

Source: compiled by authors based on data from MF (2017) and NBS (2017).

the construction of an innovative economy in Moldova was postponed indefinitely and can only remain a myth. Now it is necessary at least to stop the sharp decline in public funding and urgently seek new alternative sources for this purpose.

\section{Favorable conditions and obstacles for innovative development in the Republic of Moldova}

Today there are both favorable conditions and obstacles to innovation development of the economy of the Republic of Moldova. Favorable conditions are:

- the availability of a relatively developed scientific and technological base, which is represented by research organizations. According to the National Bureau of Statistics, 64 companies are engaged in research and development, including 40 research institutes or centers, 15 universities and 9 other types of organizations;

- the availability of scientific capacity (human and intellectual capital), which plays a vital role in the prosperity of nations. In organizations of science and innovation work 3212 researchers, including 434 doctors habilitates and 1383 of doctors in science;

- the geographical proximity to the EU and a large market;

- the innovation policy has become a priority for a number of government departments;

- the widespread access to the Internet;

- the presence of foreign banking institutions in the domestic capital market, etc.

Obstacles to the innovation development of the economy of the Republic of Moldova:

- low level of technological structure of export of the republic. Thus, the share of high-tech products in exports is only 7 per cent (Dumitrasco 2012), which mainly includes the products of the pharmaceutical industry; 
- no demand for innovations by the authorities and a large part of the population;

- the low level of communication between the research sphere and the business;

- a large outflow abroad of achievements of the Moldovan science and media, scientists, designers, especially among the talented youth;

- the limited size of the intellectual property market, which is not enough for the modernization of the economy;

- the lack of statistical information on the activities of innovative companies, etc.

Thus, basic problems of science and innovation in the country are insufficient funding; obsolete material and technical base; low rates of technology transfer, the weak involvement of young professionals in the research process; insufficient integration into the international and European Research Area; ineffective encourage of partnerships with small and medium-sized enterprises and the manufacturing sector.

\section{System of ensuring economic security of enterprises}

Unfortunately, not all entrepreneurs are aware of the importance of establishing a reliable system of economic security of enterprise and determination of the main directions of its implementation. The instability and the obstacles under which businesses operate requires from them a constant adaptation, adoption and improvement of the measures of ensuring the economic security to achieve the economic and social goals of the business, its innovative development.

The system of ensuring economic security (Fig. 3) of the enterprise represents a set of organs, tools, methods, and events, aimed at protecting the business from the actual and / or the potential external and internal threats that could lead to economic losses.

The purpose of this system is to ensure the efficient operation and sustainable development of the enterprise based on implemented set of measures. Authors identify four phases.

The first phase of ensuring the economic security is planning. It involves not only the ability to take all the necessary actions, but also to anticipate any surprises that may arise, and be able to deal with them. Enterprises cannot eliminate all threats and risks in their activities, but they can prevent and counteract them through the planning system.

The second phase involves the monitoring of external environment and internal condition of the enterprise. There are principles which apply of continuity of observation of the enterprise by considering the actual state and tendencies of its potential development, as well as the development of the economy, the political situation, and other factors.

The third phase includes the identification and implementation of measures to respond to threats. The economic security of business entities is provided by the implementation of two approaches: based on preventive measures and the approach that responds to threats. The ensuring of economic security of the enterprise is carried out by its main functional components: financial, personnel, production, technological and innovative components. These measures can be both proactive and reactive, depending on the specific situation. 


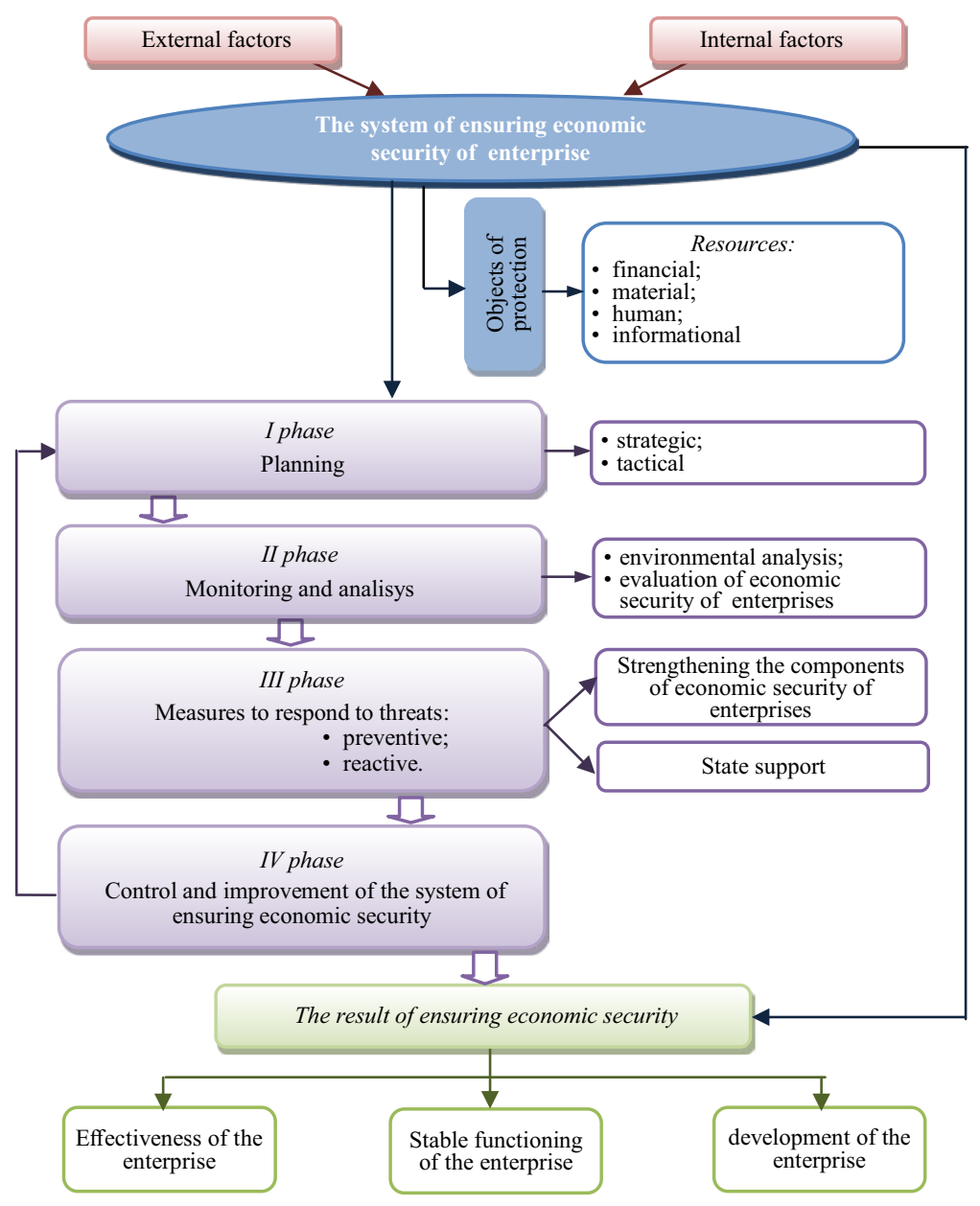

Fig. 3. System of ensuring economic security of the enterprise Source: compiled by authors.

The fourth phase represents the control and improvement of the system of economic security. The system of economic security is not a static phenomenon, but a living organism that requires ongoing management and improvement.

Main results of ensuring economic security of the enterprise should be achieving its economic performance and staff security that will allow enterprise to ensure sustainable development and achievement of business goals.

\section{Economic mechanism of improving innovative activity of enterprises}

One of the major threats to economic security of enterprise is a low level of innovation activity. This is due to the use of obsolete technologies, imperfect methods and forms of production organization and management, ineffective scheme of interaction of scientific institutions with innovative structures ant others. All this leads to higher costs and lower 
competitiveness. Therefore, it is necessary that, the formation of the economic mechanism leads to increase innovative activity of enterprises in the real sector of economy, which includes the following main directions:

- Strategic innovation management represents the prediction of changes in the economic situation and focuses on achieving future results directly through the creation and development of innovations. It aims to develop measures, programs and projects to achieve the objectives on the basis of R\&D capacity, production capacity of enterprises, external and internal factors, consumer demand;

- Innovation planning includes a set of tools, rules, information, and processes to achieve the goals.

- The system of financing innovative processes include multi-channel sources of financial resources, the principles of investing accumulated funds, a mechanism for monitoring the use of investments, evaluation of the effectiveness of innovative projects;

- The taxation of enterprises that create and use innovations. Here, the state has considerable role, for example providing tax benefits to enterprises that modernize their production, and reduction of customs duties on equipment purchased abroad, in order to renew fixed assets.

- Strategic and tactical innovative marketing, aimed at maintaining the company's competitiveness and entering new markets. Innovative marketing considers market research, management of the production and sale of innovative products.

- Pricing of innovative products and services. Pricing policy of the company for innovative products should be in accordance with a specific marketing strategy.

- State support and stimulation of innovation activity. State support should be focused on funding innovative programs, research and production farms, where it is checked the practical application of scientific and technological developments in specific circumstances (Lomovtseva, Trofimova 2014).

Even the successful start of operation of the young Moldovan innovative companies does not guarantee further development: big businesses do not need them, but they cannot afford to survive on their own. The reluctance of the large businesses to buy innovations represents one of the key problems of the republic. Young innovators are facing bureaucratic obstacles in the ministries, sell abroad ideas and technology themselves or leave the country.

The Republic of Moldova must inherit experience of developed countries (Japan, China, Singapore, Finland and others), which had favorable innovation climate in the country and carried out their innovative leaps by creating the conditions to inventors so that they do not migrate.

It seems that, solving the issues in the field of innovation is necessary to begin, firstly, with a positive attitude of the government and population. Increase the desire to innovate in all areas of our lives. The lack of knowledge must be eliminated in the area of innovation by disseminating information on the positive impact of innovation on the economy of the republic and on the level of welfare of the population. 
Secondly, it is necessary to start with the real innovative analytical software, widely use independent experts. Politicians and officials should consider their opinion. Experts (in scientific and industrial sectors) have to analyze the level of innovation in the country, and to determine what kind of foreign experience in the field of innovation can be adapted to the conditions of Moldova. Next, it is necessary to accumulate all the information together and show how it will work in practice.

Thirdly, the innovative development is possible with the state supports. Innovative sphere can really exist in the country only with the participation of the state, since it generates the appropriate institutions, laws, rules, and regulations.

Some of the directions of ensuring innovative development of the country, on the example of the Republic of Moldova are listed below:

- the development of the most modern technological trends in the priority sectors of the economy of the country, as information technology, food, agriculture, tourism, telecommunications, winemaking, production of construction materials, nanotechnologies and new materials, design and beauty industry, biotechnology, medicine;

- the active functioning of the state program of support for small and medium enterprises, as well as the adoption of a package of measures to create preferential treatment activities in the start period for small innovative businesses;

- the development and implementation of the system of guarantees and benefits that will be provided to domestic and foreign investors, who are going to invest their funds in promising innovative projects and programs;

- the increase of innovation activity of the private sector due to effective public incentives through tax, customs and tariff regulation;

- the training of qualified personnel for the implementation of innovative programs and projects, wide attraction of graduated and undergraduate students.

The proposed measures in order to increase technological and innovative component of economic security of enterprise involve:

- monitoring of the market development of high technologies and competitors' actions;

- planning of technological development of the enterprise;

- ensuring the competitiveness of technologies used at the enterprise;

- the sale or utilization of technologically and physically obsolete equipment;

- the modernization of the technical equipment of the enterprise;

- introduction of the new innovative technologies in the production process;

- the use of the competitive advantages to attract investments;

- to increase the qualification of managers and specialists involved in the innovation activity;

- promoting the inventive and innovative activities of employees and others. 


\section{Conclusions}

The Western and Eastern studies on economic security were systematized in this article. The analysis of the conceptual apparatus of the category "economic security" has shown that, there are five main approaches to define it.

Innovations are one of the key to successful economic and social development. Innovative development involves the use of innovative technologies that improve productivity, product quality and its competitiveness. The study, focused on the Republic of Moldova - one of the poorest country in Europe, showed that the R\&D\&I system faces significant problems caused by insufficient provision of financial resources and the way it is managed. It was stated that the only way to overcome the crisis and ensure the further prosperity of the country is the choice of an innovative way of development based on economic modernization and technological development.

The system of ensuring the economic security of enterprise was presented. It consists of four main phases: planning; monitoring of the external environment and internal conditions of enterprise; implementation of measures to respond to threats; the control and improvement of the system of economic security. In addition, the main directions of increasing innovative component of economic security of enterprise were presented.

The results of the presented research are important for the development of the economic science, as they represent a systematization of different approaches of the economic security with the focus on its innovative component. The developed system with its main phases and proposed measures may be implemented by the management at different levels in order to strengthen the innovative activity and the economic security of enterprises, taking into account the features of the specific industry and the specific environment of a country.

Innovations represent an important factor of the success and the well-being of economic entities and the whole economy. The same time, further research is required. It may focus on presented features and detailed directions to improve other components of economic security.

\section{References}

Artemenko, L. 2016. The system of enterprise economic security: international and Ukrainian content, World Scientific News 57: 695-705.

Baldwin, D. A. 1997. The concept of security, Review of International Studies 23: 5-26.

https://doi.org/10.1017/S0260210597000053

Blinder, A. S.; Lo, A.W.; Solow, R. M. 2012. Rethinking the financial crisis. New York: Russell Sage Foundation.

Buzan, B.; Hansen, L. 2009. The evolution of international security studies. Cambridge: Cambridge University Press. https://doi.org/10.1017/CBO9780511817762

Dynan, K. E. 2016. Household economic security and public policy, Business Economics 51(2): 83-89. https://doi.org/10.1057/be.2016.18

Dumitrasco, M. 2012. Evaluation of some parameters of export-oriented economic model, in Conference proceedings Progrese in teoria deciziilor economice in conditii de risc si incerti- 
tudine, Capitolul I: Provocari in domeniul managementului, 16 October 2012, Iasi, Romania. National Institute for Economic and Social Research "GH. ZANE", 9-18.

Ford, G. 2003. Moya zhizn', moi dostizheniya. Segodnya i zavtra [My life, my achievements. Today and tomorrow]. Minsk: Harvest (in Russian).

Freeman, N. J.; Bartels, F. L. 2004. The future of foreing investment in Southeast Asia. London: Routledge Curzon.

Gaponenko, V. F.; Bespal'ko, A. A.; Vlaskov, A. C. 2007. Ekonomicheskaya bezopasnost'predpriyatiy. Podkhody i printsipy [Economic security of enterprises. Approaches and principles]. Moskva: Izdatel'stvo Os'-89 (in Russian).

GII 2017. 2017. The Global Innovation Index 2017: The Word Innovation Feeding. Ithaca, Fontainebleau, and Geneva: Cornell University, INSEAD, and WIPO.

Hacker, J. S.; Huber, G. A.; Nichols, A.; Rehm, P.; Schlesinger, M.; Valletta, R.; Craig, S. 2014. Economic security index: a new measure for research and policy analysis, Review of Income and Wealth 60(S1): S5-S32. https://doi.org/10.1111/roiw.12053

Hindle, K.; Klyver, K. 2011. Handbook of research on new venture creation. Cheltenham UK: Edward Elgar. https://doi.org/10.4337/9780857933065

IDIS "Viitorul". 2014. Financing of small-scale and medium-scale enterprises in the Republic of Moldova: challenges, trends. Chisinau.

Ianioglo, A.; Polajeva, T. 2016. Origin and definition of the category of economic security of enterprise, in $9^{\text {th }}$ International Scientific Conference proceedings "Business and Management 2016”, 12-13 May 2016, Vilnius, Lituania, 1-8. https://doi.org/10.3846/bm.2016.46

Ioan-Franc, V; Diamescu, M. 2010. Some opinions on the relation between security economy and economic security, Romanian Journal of Economics 31: 129-159.

Lomovtseva, A. V.; Trofimova, T. V. 2014. Innovatsionnaya aktivnost' i formirovanie ekonomicheskoy bezopasnosti predpriyatiy [Innovative activity and formation of economic security of enterprises], Social Science Research Network [online], [cited 14 May 2017]. Available from Internet: https://ssrn.com/abstract=2390849 89 (in Russian).

Maier, L. 2014. The implementation of innovations in business in the Republic of Moldova, Theoretical and Scientific Journal of Economy and Sociology 3: 172-184.

MF. 2017. Report on the state budget execution [online], [cited 07 September 2017]. Ministry of Finance of the Republic of Moldova. Available from Internet: http://old.mf.gov.md/en/reports/

NBS. 2017. Main macroeconomic indicators of system of national account [online], [cited 07 September 2017]. National Bureau of Statistics of the Republic of Moldova. Available from Internet: http://www.statistica.md/category.php?1=en\&idc=191\&

OECD. 2017. Gross domestic spending on $R \& D$ (indicator). Organisation for Economic Cooperation and Development. https://doi.org/10.1787/d8b068b4-en

Raczkowski, K. 2012. Economic security. Challenges for management of the state. Warsaw: Wolters Kluwer.

Raudeliūnienè, J.; Tvaronavičienè, M.; Dzemyda, I. 2014. Towards economic security and sustainability: key success factors of sustainable entrepreneurship in conditions of global economy, Journal of Security and Sustainability 3(4): 71-79. https://doi.org/10.9770/jssi.2014.3.4(7)

Roşca, P. 2004. Economia întreprinderii [Enterprise economy]. Chişinau: ULIM (in Romanian).

Shutyak, Y.; Danylenko, O.; Van Caillie, D. 2014. Conceptualization of economic security of the enterprise: a literature review, in $3^{\text {rd }}$ REDETE Conference "Economic Development and Entrepreneurship in Transition Economies", 10 April 2014, Banja Luka, Bosnia and Herzegovina, $145-152$. 
Stone, M. 2009. Security according to Buzan: a comprehensive security analysis, Security Discussion Papers, 1. New York: Columbia University.

Stratan, I. 2007. Bezopasnost' biznesa [Business security]. Chisinau: Elan - Poligraf (in Russian).

Strelcova, S.; Rehak, D.; Johnson, D. 2015. Influence of critical infrastructure on enterprise economic security, Communications 1: 105-110.

Suglobov, A. et al. 2013. Ekonomicheskaya bezopasnost' predpriyatiya [Economic security of enterise]. Moskva: Juniti - Dana (in Russian).

Tambovctsev, V. 1995. Ekonomicheskaya bezopasnost' khozyaystvennykh sistem: struktura, problemy [Economic security of economic systems: structure, problems], Vestnik MGU 3: 3-9 (in Russian).

Tamošiūnienè, R.; Munteanu, C. 2015. Current research approaches to economic security, in $1^{\text {st }}$ International Conference on Business Management, 2-3 July 2015, Valencia, Spain. Universitat Politècnica de València, 62-65. https://doi.org/10.4995/ICBM.2015.1537

Trott, P. 2008. Innovation management and new product development. $4^{\text {th }}$ ed. Harlow: Pearson Education Limited.

Tsereteli, M. 2008. Economic and energy security: connecting Europe and the Black Sea-Caspian region. Singapore: Central Asia-Caucasus Institute and Silk Road Studies Program.

Vechkanov, G. 2007. Ekonomicheskaya bezopasnost' [Economic security]. SPb.: Piter (in Russian).

Vivchar, O. 2016. Management system interpreting financial and economic security business in economic processes, IEJME - Mathematics Education 11(4): 947-959.

Wysokińska-Senkus, A.; Raczkowski, K. 2013. Economic security in the context of sustainability, Rural Development 6(1): 454-462.

Alina IANIOGLO. PhD in Economic Sciences, lecturer at the Faculty of Economics, Comrat State
University, Republic of Moldova. Research interests: Economic Security, Innovations, Risk Manage-
ment.

Tatjana POLAJEVA. Dr Sc. (ec), Prof. at the Faculty of Business Management, EuroAcademy, Estonia. Research interests: International Economics, Business Administration, Business Economics, Economic Security, Business Communication. 